\title{
Possible Predictors of Poor Angiogenesis after Hematopoietic Stem Cell Autograft for Lower Limb Ischemia
}

\author{
Rafael A. Gómez MD, Julio D. Fernández MD, Maritza Cabrera MD, Ivón Marrero MD, Nancy Ramírez MD, Ivet Álvarez MD
}

\begin{abstract}
INTRODUCTION The therapeutic potential of adult stem cells in coronary and peripheral arterial diseases has been proposed in recent years. However, factors possibly predictive of unfavorable angiogenic results have not been clearly identified as yet.
\end{abstract}

OBJECTIVES Identify candidate predictors of poor angiogenesis, as indicated by need for amputation, after autologous hematopoietic stem cell transplantation for chronic lower limb ischemia.

METHODS A retrospective analytical case-series study was carried out to detect factors possibly associated with hematopoietic stem cell autograft failure due to low angiogenic potential. The study universe was composed of 47 patients (19 women, 28 men) with critical lower limb ischemia in Fontaine stages IIb, III and IV, who received autologous stem cell transplantation at the Dr Gustavo Aldereguía Lima University General Hospital in Cienfuegos, Cuba, from January 2007 through December 2010. Variables studied were sex, age, medical history (high blood pressure, ischemic cardiomyopathy, diabetes mellitus and chronic renal insufficiency), Fontaine ischemia stage, intermittent claudication, pain score on a 1-10 scale, ankle-brachial pressure index in the affected extremity, presence of ulcers, and smoking. Laboratory variables included: blood concentrations of hemoglobin, glucose, creatinine, liver enzymes, cholesterol, triglycerides and LDH; as well as

\section{INTRODUCTION}

In recent years, basic and clinical research on the therapeutic potential of stem cells, particularly adult stem cells, has virtually revolutionized medicine. Some types of adult stem cells have been found to have an ability greater than previously thought to differentiate into cells of different lineages, under certain conditions.[1] Regenerative cell therapy, the new modality employing these hematopoietic stem cells (HSC) for regenerative purposes, is of great interest to the scientific community-as once were its predecessors, blood transfusion and bone marrow transplantation, now routine procedures of recognized value.[1]

Bone marrow contains not only HSCs, but also other types of cells, including endothelial progenitor cells (EPC) from the embryonic hemangioblast and mesenchymal stem cells-the latter gaining clinical significance in recent years due to their therapeutic potential. Lately, cells with pluripotent capacity, called very small embryonic-like cells, have also been described. Mononuclear cells (MNC) derived from bone marrow constitute a sort of "cocktail" of different adult stem cells, among them endothelial cells, which has facilitated their extensive use in diseases with an ischemic component.[1]

One such condition is chronic lower limb ischemia, which results from a slow, progressive decrease in blood flow that reduces oxygen supply to the leg muscles during exercise.[2] Development of collateral circulation allows tissue ischemia to remain silent until vessel lumen obstruction exceeds $70 \%$, at which time the cardinal symptom appears: intermittent claudication, muscle pain on walking that disappears at rest.[3] Disease progression is slow; after 5 to 10 years of followup, more than $70 \%$ of the patients show no leukocyte and platelet counts, stem cell viability, prothrombin time and erythrocyte sedimentation rate. The main response variable was amputation, an indicator of poor angiogenesis. Using logistic regression, a prognostic score of 1 to 4 was developed for each risk factor and scores added to create a risk prediction scale. Predicted risk for amputation and observed amputation rates were compared for patients in three risk groups: low, 0-4; medium, 5-8; and high, 9-12.

RESULTS Factors identified as possibly predictive of poor angiogenesis were: final leukocyte count $<20 \times 10 \%$ after mobilization with granulocyte colony stimulating factor; age $\geq 60$ years; pain scale score of 10; glycemia of $>6 \mathrm{mmol} / \mathrm{L}$; and triglycerides of $>1.8 \mathrm{mmol} / \mathrm{L}$. Patients who scored low on predicted amputation risk scale were spared amputation in $90.9 \%(10 / 11)$ of cases, versus $16.7 \%(2 / 12)$ in patients scoring high.

CONCLUSIONS Five possible prognostic factors for low angiogenic potential in stem cell autotransplantation were identified and a preliminary scale established to predict in which patients autotransplantation would be more likely to be successful.

KEYWORDS Adult stem cells, autologous transplantation, autografting, peripheral occlusive disease, peripheral artery disease, ischemia, prognosis, amputation, risk factor, Cuba

changes in symptoms, while 20 to $30 \%$ have worsening symptoms requiring intervention.[4,5]

Prevalence of chronic lower limb ischemia based on physical examination ranges between 5 and $10 \%$ in the population aged 55-65 years and between 10 and $15 \%$ in those aged $>65$ years. When hemodynamic tests are performed, prevalence rises to $20-25 \%$ in patients aged $55-65$ years and over $30 \%$ in those aged $>65$ years. [6] Prevalence at necropsy data is $30-40 \%$ in those aged $55-65$ years and over $60 \%$ in those aged $>65$ years. [7] Incidence of the most severe form, critical ischemia, has been estimated at 500 cases per million population per year worldwide, [8] which would correspond to 6000 new cases annually in Cuba's population of approximately 12 million.

Recent technological developments and use of advanced experimental animal models have led to new strategies to treat ischemia, especially in the legs. Some have already shown promising results in clinical trials. $[9,10]$

The body's ability to spontaneously develop collateral circulation is an important positive factor in response to occlusive vascular disease and decisively affects severity of residual tissue ischemia. Neoangiogenesis (new vessel formation) and vasculogenesis (formation of new vessels from pre-existing ones) may be sufficient to preserve muscle tissue integrity and function, and so have been the basis for developing new treatment approaches.[11,12]

Angiogenesis is a dynamic process of endothelial cell proliferation and differentiation in which new functional vascularization 
results from the coordinated activity of endothelial cells, extracellular matrix and surrounding cells. Vascular growth factors are among the major physiological stimuli of angiogenesis; these include the prototype vascular endothelial growth factor and others, such as angiopoietins 1 and 2 (Ang-1, Ang-2), transforming growth factor- $\beta$ and basic fibroblastic growth factor. Some of these angiogenic factors, mainly vascular endothelial growth factor and fibroblastic growth factor, have already been used in human clinical trials for ischemic cardiomyopathy and lower limb ischemia.[13]

These trials have generally used only one growth factor, a limitation when studying a process that requires interaction among several elements, EPCs among them-hence, the suggestion that future trials employ combinations of different angiogenesis growth factors. However, such procedures are more complex and expensive, requiring highly specialized laboratories.[14]

One alternative is to provide cells that can influence growth factor release or EPCs that can directly affect angiogenesis.[15] It has recently been shown that adult bone marrow is a rich reservoir of several types of EPCs and HSCs that can contribute to vascularization, both during the physiological embryonic period and postnatally.[16] Due to its potential angiogenic effect, autologous implantation of bone marrow-derived mononuclear stem cells is being implemented to good effect in patients with severe ischemic complications, in what has been described as "a revolution in regenerative medicine."[17,18]

The advantage of cell therapy to induce angiogenesis is that it could promote endothelial regeneration and release of several angiogenic growth factors. Furthermore, the existence has been established of cell subpopulations in bone marrow that can differentiate into myogenic and vascular cells (angiomyogenesis). [17] Autologous bone marrow MNC transplantation has been proposed as a safe and effective angiogenic therapy, because of these cells' natural property of yielding EPCs and several angiogenic factors and cytokines.[19]

To date, there is scant literature on prognostic factors for autologous HSC transplantation for ischemic conditions; nor is there much on associated adverse effects. There are conflicting results regarding its true benefit, and it has been observed that individual patient characteristics decisively influence outcomes. A REPAIR-AMI study analysis subgroup found larger infarcted area and left ventricular dysfunction to be associated with greater autotransplantation success rates.[20] The BOOST study concluded that transplant success did not depend on patient age, nor degree of dysfunction, nor therapy timing but rather was influenced by presence of diabetes and other chronic conditions; $[21,22]$ experimental studies have also demonstrated that diabetes and other systemic diseases significantly reduce HSC angiogenic potential.[23]

The conclusion from all this? Stem cell therapy can be beneficial, but not for all patients. Hence the importance of identifying patients who are most likely to benefit. Identification of prognostic factors could help determine the most appropriate candidates, avoiding raising false expectations in those patients who would not benefit. This would also be a contribution to health systems' rational use of human and financial resources, both substantially implicated in this form of treatment.
There have been no Cuban studies of possible factors associated with poor angiogenic response after autologous HSC transplantation, an indisputably important question for deciding which patients are best candidates for this therapy. Our objective, then, was to identify clinical and laboratory factors that could suggest poor prognosis for angiogenesis after HSC autograft in patients with chronic lower limb ischemia and to establish a preliminary scale to stratify patients by risk.

\section{METHODS}

Study type and population A retrospective analytical study was carried out of a case series of 47 adult patients with lower limb ischemia who underwent autologous HSC transplantation in the Dr Gustavo Aldereguía Lima University General Hospital in Cienfuegos, Cuba, between January 2007 and December 2010. Patients with incomplete clinical or laboratory records were excluded.

Data source Data on variables selected were taken entirely from clinical records of patient care from prior to autotransplantation through follow up.

Study variables Independent clinical and laboratory variables assessed are summarized in Table 1. The dependent variable, successful angiogenesis, was defined by avoidance of amputation for one year post-transplantation.

Table 1: Study variables

\begin{tabular}{|c|c|}
\hline Variable & Description \\
\hline Age (years) & $\begin{array}{l}\geq 60 \\
<60\end{array}$ \\
\hline Sex & Male, female \\
\hline Diagnosis & $\begin{array}{l}\text { Arteriosclerosis obliterans } \\
\text { Ischemic diabetic foot (according to } 10^{\text {th }} \text { ICD)[24] }\end{array}$ \\
\hline Medical history & $\begin{array}{l}\text { Bronchial asthma, chronic renal insufficiency, } \\
\text { diabetes mellitus, hypertension, ischemic heart } \\
\text { disease, smoking }\end{array}$ \\
\hline Fontaine stage & Fontaine scale grades I, Ila and IIb, III, IV[25] \\
\hline $\begin{array}{l}\text { Claudication distance } \\
(\mathrm{m})\end{array}$ & $\begin{array}{l}\text { Distance in meters until claudication appears } \\
<50 \mathrm{~m} \\
\geq 50 \mathrm{~m}\end{array}$ \\
\hline Pain scale $(0-10)$ & $\begin{array}{l}\text { Perceived pain: } 0=\text { no pain, } 10=\text { maximum } \\
\text { pain }\end{array}$ \\
\hline $\begin{array}{l}\text { Ankle/brachial pres- } \\
\text { sure index }\end{array}$ & $\begin{array}{l}\text { Lower limb blood pressure/upper limb blood } \\
\text { pressure } \\
\text { Normal: } 1.0\end{array}$ \\
\hline Ulcers & Lower limb skin integrity: Yes/No \\
\hline Hemoglobin (g/dL) & Normal range: Men 13-17.5 Women 12-16.5[26] \\
\hline $\begin{array}{l}\text { Total leukocyte count } \\
\text { (x 10\%/L) }\end{array}$ & $\begin{array}{l}\text { Normal: } 4.0-12.0[26] \\
\text { (measured pre- and postmobilization with } \\
\text { granulocyte colony stimulating factor) }\end{array}$ \\
\hline Glycemia (mmol/L) & Normal: $3.8-5.88[26]$ \\
\hline Creatinine $(\mathrm{mmol} / \mathrm{L})$ & $\begin{array}{l}\text { Normal: Men } 62-106 \mathrm{mmol} / \mathrm{L} \\
\text { Women } 44-80 \mathrm{mmol} / \mathrm{L}[26]\end{array}$ \\
\hline SGPT (IU/L) & Normal: Men $<41$ Women $<31[26]$ \\
\hline Cholesterol (mmol/L) & Normal: 3.87-6.71 mmol/L[26] \\
\hline Triglycerides (mmol/L) & $\begin{array}{l}\text { Normal: Men } 0.68-1.80 \mathrm{mmol} / \mathrm{L} \\
\text { Women } 0.46-1.60 \mathrm{mmol} / \mathrm{L}[26]\end{array}$ \\
\hline LDH (IU/L) & Normal: $200-400[26]$ \\
\hline Leukocyte viability & Optimal: $>90 \%$ \\
\hline Platelet count & Normal: $150-350 \times 10^{9} / \mathrm{L}[26]$ \\
\hline Prothrombin time & Normal: $11.2-13.2 \mathrm{sec}[26]$ \\
\hline ESR & Normal: Men 1-10 mm/h Women $1-20 \mathrm{~mm} / \mathrm{h}[26]$ \\
\hline Amputation & Supracondylar lower limb amputation: Yes/No \\
\hline
\end{tabular}

ESR: erythrocyte sedimentation rate LDH: Lactic dehydrogenase 
Measurement of ankle/brachial pressure Blood pressure was measured prior to HSC implantation and 4, 8 and 16 weeks postimplantation. The ankle-brachial pressure index was calculated by dividing lower limb systolic pressure (attained by Doppler ultrasonic flow meter) by systolic arm pressure (measured by conventional auscultation) with the patient lying supine.[27] Posterior tibial and lower dorsal pedal artery pressures lower than brachial pressures indicated important arterial obstruction. In borderline cases, measurements were taken before and after exercise.

MNC separation method The procedure used by Hernández[1] was followed to mobilize peripheral blood MNCs: patients were given $10 \mu \mathrm{g} / \mathrm{kg}$ of domestically-manufactured recombinant human granulocyte colony stimulating factor (LeukoCIM, CIMAB SA, Cuba) subcutaneously every 12 hours for a total of 4 doses. Three hours after the last injection, $800-1000 \mathrm{~mL}$ of whole blood were extracted, amount depending on the patient's clinical condition. MNCs were then concentrated by sedimentation after adding 1 $\mathrm{mL}$ of $6 \%$ hydroxyethyl starch per $6 \mathrm{~mL}$ whole blood.

MNC and HSC count and assessment of leukocyte viability To evaluate viability and cell count, Hernández's method[1] was used, with slight modifications dictated by resource limitations in our institution: a small fraction of cell suspension was used for cell count, viability testing by trypan blue exclusion and microbiology. Cell count pre- and postmobilization was performed in a Neubauer chamber, since an automatic cell counter was not available. All readings were done by the same observer to avoid interobserver error, the main limitation of this method. To reduce intraobserver error, duplicate readings of each sample were performed and averaged. Differential cell count was carried out by optical microscopy of cell concentrate stained with May-Grünwald Giemsa. Lymphocytes, monocytes, lymphocytoid and monocytoid cells, immature myeloid cells, proerythroblasts and erythroblasts were considered MNCs. MNC concentration was not available in all patient records so not used in prognostic analysis. Mean MNC concentration for 34 patients was $2.5 \times 10^{\%} / \mathrm{L}$.

MNC implantation MNC were injected intramuscularly in the gastrocnemius and quadriceps muscles, per Hernández.[1]

Data processing Percentages were calculated for general variables: sex, medical history and Fontaine stages;[25] mean and standard deviation were calculated for age. Results were presented in frequency distribution tables. Logistic regression analysis was used to study categorical variables representing possible prognostic factors for deficient angiogenesis. In univariate logistic regression, variables showing a coefficient of $\leq 0.1$ ( $p \leq 0.10$ ) were considered prognostic factors, due to small sample size. Values from one to four were assigned to variables when their $p$ values corresponded to $0.10,0.05$, 0.025 , and 0.01 respectively; these values were cumulated to create a preliminary scale, modeled on the approach for MNC autograft in the heart,[28] the only one found in the literature for similar purposes. The significance level was set at $p \leq 0.05$. Data were processed using SPSS 15.0 Windows statistics.

Ethical considerations The study relied exclusively upon administrative data, taking measures to ensure patient anonymity. It was approved by the ethics committee of Dr Gustavo Aldereguía Lima University General Hospital.

\section{RESULTS}

Mean patient age was 64 years; male sex predominated $(59.6$ $\%$ ). Hypertension (HT) and diabetes were concurrent in $23.4 \%$ (11); a further $17 \%$ (8) had both these conditions plus ischemia cardiomyopathy; and $17 \%$ reported smoking. Fontaine stage IV predominated, with $53.2 \%$ (25) (Table 2).

Regression analysis of clinical parameters revealed age $\geq 60$ years and a pain scale score of 10 to be significant, resulting in prognostic scores of 3 and 2 points, respectively (Table 3 ).

Regression analysis of laboratory values found final leukocyte count of $<20 \times 10^{9} / \mathrm{L}$ and glycemia of $>6 \mathrm{mmol} / \mathrm{L}$ to be significant, for prognostic scores of 4 and 2 , respectively. The final variable to enter the scale was triglyceride level, with a prognostic score of 1 (Table 4).

Thus, five variables were identified as potential predictors of poor prognosis for angiogenesis in autotransplanted patients: post-

Table 2: Patient characteristics $(n=47)$

\begin{tabular}{|c|c|c|c|}
\hline Age & & Mean & Range \\
\hline \multirow[t]{2}{*}{ Age (years) } & & 64 & 29-84 \\
\hline & & $\mathbf{n}$ & $\%$ \\
\hline \multicolumn{4}{|l|}{ Sex } \\
\hline Male & & 28 & 59.6 \\
\hline Female & & 19 & 40.4 \\
\hline \multicolumn{4}{|l|}{ Medical history } \\
\hline $\mathrm{HT}+\mathrm{DM}$ & & 11 & 23.4 \\
\hline $\mathrm{HT}+\mathrm{IHD}+\mathrm{DM}$ & & 8 & 17.0 \\
\hline Smoking & & 8 & 17.0 \\
\hline HT & & 6 & 12.8 \\
\hline$H T+I H D$ & & 4 & 8.5 \\
\hline NA & & 4 & 8.5 \\
\hline DM & & 2 & 4.3 \\
\hline CRI & & 1 & 2.1 \\
\hline$H T+I H D+D M+C R I$ & & 1 & 2.1 \\
\hline DM + Smoking & & 1 & 2.1 \\
\hline Bronchial asthma & & 1 & 2.1 \\
\hline \multicolumn{4}{|l|}{ Fontaine stage } \\
\hline IV & & 25 & 53.1 \\
\hline III & & 14 & 29.7 \\
\hline $\mathrm{Ilb}$ & & 8 & 17.2 \\
\hline $\begin{array}{l}\text { IHD: Ischemic heart disease } \\
\text { HT: Hypertension } \\
\text { NA: Nonsmoker with none of }\end{array}$ & $\begin{array}{l}\text { DM: Diabet } \\
\text { CRI: Chron } \\
\text { diseases }\end{array}$ & $\begin{array}{l}\text { ellitus } \\
\text { hal insufficiency }\end{array}$ & \\
\hline
\end{tabular}

Table 3: Regression analysis and risk scores of clinical variables

\begin{tabular}{|l|r|r|r|}
\hline Variable & $\begin{array}{c}\text { Regression } \\
\text { coefficient }\end{array}$ & p Value & Risk Score \\
\hline Age $\geq 60$ years & 0.330 & 0.024 & 3 \\
\hline Pain scale = 10 & 0.650 & 0.034 & 2 \\
\hline Chronic renal insufficiency & 0.264 & 0.711 & - \\
\hline Fontaine IV & 0.249 & 0.091 & - \\
\hline Ulcers & 0.243 & 0.100 & - \\
\hline Fontaine III & 0.234 & 0.628 & - \\
\hline Hypertension & 0.220 & 0.355 & - \\
\hline Fontaine Ilb & 0.203 & 0.401 & - \\
\hline Ankle-brachial index & 0.151 & 0.388 & - \\
\hline Smoking & 0.127 & 0.721 & - \\
\hline Claudication distance $<50 \mathrm{~m}$ & 0.033 & 0.827 & - \\
\hline Female sex & 0.045 & 0.766 & - \\
Male sex & 0.045 & 0.766 & - \\
\hline Diabetes mellitus & 0.026 & 0.895 & - \\
\hline Ischemic heart disease & 0.025 & 0.873 & \\
\hline
\end{tabular}


Table 4: Regression analysis and risk scores, laboratory variables

\begin{tabular}{|c|c|c|c|}
\hline Variable & $\begin{array}{l}\text { Regression } \\
\text { coefficient }\end{array}$ & p Value & Risk score \\
\hline $\begin{array}{l}\text { Postmobilization leukocyte } \\
\text { count }<20 \times 10^{9} / \mathrm{L}\end{array}$ & 0.576 & 0.001 & 4 \\
\hline Glycemia >6 mmol/L & 0.291 & 0.047 & 2 \\
\hline Triglycerides $>0.8 \mathrm{mmol} / \mathrm{L}$ & 0.321 & 0.071 & 1 \\
\hline Cholesterol >5.0 mmol/L & 0.225 & 0.128 & - \\
\hline $\begin{array}{l}\text { ESR > } 10 \mathrm{~mm} / \mathrm{h} \text {, men; >20 } \\
\mathrm{mm} / \mathrm{h} \text {, women }\end{array}$ & 0.135 & 0.366 & - \\
\hline LDH >400 IU/L & 0.132 & 0.377 & - \\
\hline $\begin{array}{l}\text { Premobilization leukocyte } \\
\text { count }<20 \times 10^{9} / \mathrm{L}\end{array}$ & 0.130 & 0.578 & - \\
\hline Platelet count $<100 \times 10^{9} / \mathrm{L}$ & 0.115 & 0.440 & - \\
\hline Prothrombin time $>13.2 \mathrm{~s}$ & 0.070 & 0.642 & - \\
\hline Leukocyte viability $\leq 90 \%$ & 0.056 & 0.710 & - \\
\hline $\begin{array}{l}\text { SGPT } \geq 41 \text { IU/L men; } \geq 31 \\
\text { IU/L women }\end{array}$ & 0.026 & 0.862 & - \\
\hline
\end{tabular}

ESR: erythrocyte sedimentation rate LDH: lactic dehydrogenase

SGPT: serum glutamic piruvic transaminase

Table 5: Observed angiogenic potential by predicted $(n=47)$

\begin{tabular}{l|c|c|c|c|c|c|}
\hline $\begin{array}{l}\text { Total prognostic } \\
\text { score (predicted } \\
\text { angiogenic } \\
\text { potential) }\end{array}$ & \multicolumn{2}{|c|}{ Patients } & \multicolumn{3}{|c|}{ Observed angiogenic potential } \\
\cline { 2 - 7 } & $\mathbf{n}$ & $\%$ & $\begin{array}{c}\text { Amputated } \\
\mathbf{n}\end{array}$ & $\begin{array}{c}\text { Not } \\
\text { amputated } \\
\mathbf{n}\end{array}$ & $\begin{array}{c}\text { Amputations } \\
\text { spared } \\
\%\end{array}$ \\
\hline 0-4 (High) & 11 & 23.4 & 1 & 10 & 90.9 \\
\hline 5-8 (Intermediate) & 24 & 51.1 & 10 & 14 & 58.3 \\
\hline 9-12 (Low) & 12 & 25.5 & 10 & 2 & 16.7 \\
\hline
\end{tabular}

mobilization leukocyte count of $<20 \times 10^{\%} / \mathrm{L}$, age $\geq 60$ years, pain scale score 10 , glycemia of $\geq 6 \mathrm{mmol} / \mathrm{L}$ and triglyceride level of $>1.8 \mathrm{mmol}$. Assigned risk scores were 4, 3, 2, 2 and 1, respectively, creating a potential scale of $0-12$ for predicting risk of amputation because of poor angiogenesis.

Overall, $55.3 \%(26 / 47)$ of patients were able to avoid amputation. Of patients with scores between 0 and 4 (high predicted angiogenic potential), 90.9\% (10/11) were spared amputation. Of patients with scores between 9 and 12 (low predicted angiogenic potential), $16.7 \%$, (2/12) were spared amputation and $58.3 \%(14 / 24)$ of those in the mid range of predicted angiogenic potential (Table 5).

\section{DISCUSSION}

Clinical application of hematopoietic stem cells in diseases with an ischemic component, rapidly extending in medical practice, has two essential advantages: immunologic, because rejection is not a problem; and ethical, because the patient's own tissue is used, hence there is no risk from introduction of foreign matter. However, clinical and laboratory factors predictive of angiogenic potential and successful outcomes in individual patients have not been fully described.[29] There is no Cuban or international research on prognostic factors for autotransplantation in lower limb ischemia with which to compare our results, but clinical trials of HSC for cardiac and brain ischemia[30,31] and relevant experimental animal models do provide some context for comparison.

Aging has been implicated as an adverse prognostic factor in myocardial ischemic tissue autotransplantation, as reported by Li.[31] This is consistent with our finding that age $\geq 60$ years constituted a prognostic factor (risk score of 3 ).
Peripheral arterial ischemia is the result of different diseases affecting lower limb vascularization, generating pain, incapacity and impaired quality of life. Critical ischemia produces great morbidity, mortality and chronic pain. The maximum score of 10 on the pain scale represents the most intense pain perceived by the patient, corresponding to greater vascular damage.[32-34] Since HSCs need a minimum of circulation for nourishment to be able to initiate neoangiogenesis, it stands to reason that greater pain intensity, an indirect indication of scant vascularization, would predict low angiogenic potential, as we found. Consistent with our results, O'Neill found neovascularization capacity potentially reduced in patients with ischemic cardiomyopathy producing pain,[35] and Fernández found reduced in vitro capacity for migration and colony formation in HSCs from patients with critical lower limb ischemia and pain.[36] In our study, pain was a moderately important predictor, with a score of 2 , consistent with these and other lines of evidence.[36,37]

Adult bone marrow stem cells have many different subpopulations capable of transdifferentiation into several cell types, depending on their membrane expression markers.[38] According to their capacity for neovascularization, they can be divided into two types: CD34 positive and CD34 negative.[39] Recent experimental studies have demonstrated that CD34-positive EPCs can be mobilized into systemic circulation and can contribute to neovascularization and re-endothelialization after birth.[40,41] A decisive role in neoangiogenesis has been demonstrated for stem cell number and/or concentration.[12,42] Experimental studies in animals have shown that ischemia per se can induce stem cell mobilization to peripheral blood; particularly in mouse models, administration of granulocyte colony stimulating factor after ischemia has resulted in decreased mortality, reduced infarcted area and increased regeneration of myocytes and vascular structures.[41] However, this has not been convincingly demonstrated in clinical trials.

A larger number of MNCs mobilized to peripheral blood increases the probability that there is also a larger number of HSCs, which would improve prospects for successful neovascularization.[42] We defined this by postmobilization leukocyte count, and it resulted in the most powerful predictor of autotransplantation success, with a low count contributing four points to the scale. We therefore believe this prognostic factor to be essential for assessing likely autograft success. In fact, in the group with the best prognosis (scores 0-4), the only failure was in the single patient whose postmobilization MNC count was $<20 \times 10^{9} / \mathrm{L}$. Hernández found that most patients with postmobilization leukocyte counts of $<20 \times 10 \%$ / had low autograft success rates, and so in subsequent studies continued mobilization every 12 hours until adequate values were attained.[11] Our results reinforce the importance of continuing cell mobilization until the values are $>20 \times 10^{\%} / \mathrm{L}$, to ensure greatest likelihood of angiogenic success in the presence of other poor prognostic factors.

One of our study limitations was that incomplete patient information meant our logistic regression did not include MNC count in peripheral blood, precisely where most HSC are found. It will be critical to include this variable in any future development of a prognostic scale.

Another limitation was the use of manual methods rather than automatic counters for absolute leukocyte count. Observer error is inherent in manual counting, although we minimized interobserver error by using only one observer and intraobserver error 
by averaging repeated observations on each sample. Manual and automated counting have been found to have similar equivalence coefficients $(0.950$ vs. 0.920).[43,44] Several authors have shown that automatic hemocytometers optimize time and laboratory resources but tend to count approximately 10 cells less than manual counters and do not discriminate cell types as well as manual counters, especially in the granulocytic and erythroid lines.[43-46] This is particularly important to keep in mind in this type of study because patients receiving granulocyte colony stimulating factor mobilize large numbers of these cells into peripheral circulation and automated counting could substantially underestimate final postmobilization counts.

Diabetes mellitus is associated with increased risk of atherosclerosis and poor prognosis following vascular occlusion,[47] as well as with disturbances in endothelial cell and monocyte maturation.[48] Neovascularization does not consist only of angiogenesis but also involves bone marrow-derived EPCs, which participate in vasculogenesis, contributing $25 \%$ of blood vessel formation.[49] The number of EPCs in circulation is relatively low but increases in response to trauma or ischemia, mobilizing from bone marrow to periphery.[50]

Some studies have shown patients at risk for coronary disease and diabetes to have reduced numbers of circulating EPCs.[51] Animal research suggests diminished vasculogenesis in diabetes, since EPC proliferation and differentiation are less in diabetic than in nondiabetic animals.[52,53] Thus, we can infer that hyperglycemia should negatively influence neovascularization, exactly what we observed in this study, where diabetes was a moderately strong prognostic factor, contributing two points to the predictive scale.

Alterations in plasma lipoproteins and lipid metabolic disorders are among the most firmly established and atherosclerosis risk factors. [54] After a usually prolonged asymptomatic phase, atherosclerosis can become manifest; one clinical expression is chronic lower limb ischemia with intermittent claudication.[55] Thus, increased blood lipids, especially triglycerides, represent a direct prognostic factor, notably increasing atherosclerosis and consequently vas- cular occlusion throughout the body. This reduces nourishment availability for implanted stem cells, limiting their ability to differentiate into vessel-forming endothelial cells.[56] Increased triglycerides were a minor prognostic factor for failed angiogenesis in our study, contributing one point to the predictive scale.

The main limitations of this study that may have affected its findings are those inherent in its small sample size, its local nature and lack of randomization, possibly explaining the absence of an effect of such recognized risk factors as hypercholesterolemia, chronic renal insufficiency and advanced Fontaine stage.

The literature reviewed did not identify a predictive scale specific to HSC autotransplantation for lower limb ischemia, which led us to extrapolate ours from one used for cardiac ischemia. The scale thus developed is therefore preliminary by definition, subject to all the limitations inherent in this type of study, and requires further research and modification. Nonetheless, we have provisionally identified factors that should be taken into account when deciding which patients are most likely to benefit from HSC autograft. Our study's ultimate contribution will depend on future research to corroborate the predictive value of the possible prognostic factors found and the clinical usefulness of the risk scale developed.

\section{CONCLUSIONS}

Five clinical and laboratory variables were identified as possible predictors of poor prognosis after HSC autograft for chronic lower limb ischemia. The scale thus created has potential for classifying patients according to their high, intermediate or low angiogenic potential. Generalization of these results is subject to corroboration and refinement by further research.

\section{ACKNOWLEDGMENTS}

Thanks to Latin American Medical School students Eliana Paola Álvarez Cabral and Flavio Andrés Bovio Caltieri, for their invaluable help in data collection and to the Dr Gustavo Aldereguía Lima University General Hospital. - 1/

\section{REFERENCES}

1. Hernández-Ramírez $P$, Alfonso-Simón A, Aparicio-Suárez JL, Artaza-Sanz $\mathrm{H}$, Baganet-Cobas A, Blanco-Díaz Á, et al. Experiencia cubana con el uso terapéutico de células madre adultas. Rev Cubana Hematol Hemoter. 2011;27(1):139-63. Spanish.

2. Liu Q, Chen Z, Terry T, McNatt JM, Willerson JT, Zoldhelyi P. Intra-arterial transplantation of adult bone marrow cells restores blood flow and regenerates skeletal muscle in ischemic limbs. Vasc Endovascular Surgery. 2009 OctNov;43(5):433-43.

3. Kim MH, Zhang HZ, Kim SW. Combined growth factors enhanced angiogenic potential of cord blood-derived mononuclear cells transplanted to ischemic limbs. J Mol Cell Cardiol. 2011 Nov;51(5):702-12.

4. Lasala GP, Silva JA, Gardner PA, Minguell JJ. Combination stem cell therapy for the treatment of severe limb ischemia: safety and efficacy. Angiology. 2010 Aug;61(6):551-6.

5. Franz RW, Shah KJ, Johnson JD, Pin RH, Parks AM, Hankins T, et al. Short- to mid-term results using autologous bone-marrow mononuclear cell implantation therapy as a limb salvage procedure in patients with severe peripheral arterial disease. Vasc Endovascular Surgery. 2011 Jul;45(5):398-406.
6. Hernández P. Medicina regenerativa II. Aplicaciones, realidad y perspectivas de la terapia celular [Internet]. Rev Cubana Hematol Inmunol Hemoter. 2006 [cited 2011 Sep 19];(1). Available from: http://scielo.sld.cu/scielo.php?script=sci arttext\&pid $=$ S08642892006000100002\&Ing $=e$ s\&nrm=iso. Spanish.

7. Hernández P, Dorticós E. Medicina regenerativa. Células madre embrionarias y adultas [Internet]. Rev Cubana Hematol Inmunol Hemoter. 2004 [cited 2011 Sep 9]. Available from: http://scielo.sld .cu/scielo.php?script=sci_arttext\&pid= S0864028 $92004000300001 \&$ Ing=es\&nrm=iso. Spanish.

8. Mohler ER 3rd. Peripheral Arterial Disease. Identification and implications. Arch Intern Med. 2003 Oct 27;163(19):2306-14.

9. Hasabe H, Osada M, Kodama Y, Fujioka D, Sano K, Nakamura T, et al. [Therapeutic angiogenesis by autologous transplantation of bone marrow cells in a patient with progressive limb ischemia due to arteriosclerosis obliterans: a case report]. J Cardiol. 2004 Apr;43(4):179-83. Japanese.

10. Kolvenbach R, Kreissig C, Ludwig E, Cagiannos C. Stem cell use in critical limb ischemia. J Cardiovasc Surg (Torino). 2007 Feb;48(1):39-44.

11. Hernández P, Artaza H, Díaz AJ, Cortina LD, Lam $\mathrm{RM}, \mathrm{Pol} \mathrm{N}$, et al. Autotrasplante de células madre adultas en miembros inferiores con isquemia crítica. Rev Española Investig Quirúrgicas. 2007;4:204-11. Spanish

12. Korymasov E, Tyumina O, Rossiev V Kazantscev A, Volchkov S, Toropovskiy A. Randomized double blind placebo-controlled research of efficiency of treatment patients with lower limb arteriosclerosis obliterans by autologous transplantation of bone marrow progenitor cell. 14th Annual International Society for Cellular Therapy, Meeting, Miami 2008. Cytotherapy. 2008;10(Suppl 1):abstract 236

13. Skora J, Pupka A, Barc P, Szyber P, Polak W, Szyber P. [Complex gene-cell therapy in treatment of critical lower limbs ischemia]. Pol Merkur Lekarski. 2007 Feb;22(128):121-5. Polish.

14. Bhang SH, Cho SW, Lim JM, Kang JM, Lee TJ, Yang HS, et al. Locally delivered growth factor enhances the angiogenic efficacy of adiposederived stromal cells transplanted to ischemic limbs. Stem Cells. 2009 Aug;27(8):1976-86.

15. Tachi Y, Fukui D, Wada Y, Koshikawa M, Shimodaira $S$, Ikeda $U$, et al. Changes in angiogenesis related factors in serum following autologous bone marrow cell implantation for severe limb ischemia. Expert Opin Biol Ther. 2008 Jun;8(6):705-12.

16. Rufaihah AJ, Huang NF, Jamé S, Lee JC, Nguyen $\mathrm{HN}$, Byers B, et al. Endothelial cells derived 
from human iPSCS increase capillary density and improve perfusion in a mouse model of peripheral arterial disease. Arterioscler Thromb Vasc Biol. 2011 Nov;31(11):e72-9.

17. Lasala GP, Minguell JJ. Vascular disease and stem cell therapies. $\mathrm{Br}$ Med Bull. 2011 Jun;98:187-97.

18. Mason C, Dunnill P. A brief definition of regenerative medicine. Regen Med. 2008;3(1):1-5.

19. Hayden EC, Baker M. Virus-free pluripotency for human cells. Stem-cell advance could bring tailored treatments closer. Nature. 2009 Mar:458(7234):19.

20. Chih S, Macdonald PS, McCrohon JA, Ma D, Moore J, Feneley MP, et al. Granulocyte colony stimulating factor in chronic angina to stimulate neovascularisation: a placebo controlled crossover trial. Heart. 2012 Feb;98(4):282-90.

21. Meyer GP, Wollert KC, Lotz J, Steffens J, Lippolt $\mathrm{P}$, Fichtner S, et al. Intracoronary bone marrow cell transfer after myocardial infarction: eighteen months' follow-up data from the randomized, controlled BOOST (BOne marrOw transfer to enhance ST-elevation infarct regeneration) trial. Circulation. 2006 Mar 14;113(10):1287-94.

22. Schächinger V, Erbs S, Elsässer $A$, Haberbosch W, Hambrecht $\mathrm{R}$, Hölschermann $\mathrm{H}$, et al. Intracoronary bone marrow-derived progenitor cells in acute myocardial infarction. $\mathrm{N}$ Engl $\mathrm{J}$ Med. 2006 Sep 21;355(12):1210-21.

23. Amin AH, Abd Elmageed ZY, Nair D, Partyka MI, Kadowitz PJ, Belmadani S, et al. Modified multipotent stromal cells with epidermal growth factor restore vasculogenesis and blood flow in ischemic hind-limb of type II diabetic mice. Lab Invest. 2010 Jul;90(7):985-96.

24. WHO. ICD-10 International Statistical Classification of Diseases and Related Health Problems. 2010 Version [Internet]. Geneva: World Health Organization Library Cataloguing; 2010 [cited 2011 Oct 24]. Available from: http://www who.int/classifications

25. Becker F. Exploration of arterial function with noninvasive technics. Results in chronic arterial occlusive disease of the lower limbs according to Leriche and Fontaine classification. Int Angiol. 1985 Jul-Sep;4(3):311-22.

26. Kratz A, Lewandrowski KB. Normal reference laboratory values. N Engl J Med. 1998 Oct 8;339(15):1063-72.

27. Ebihara I, Sato T, Hirayama K, Seki M, Enami $\mathrm{T}$, Kawahara $\mathrm{H}$, et al. Blood flow analysis of the head and lower limbs by the laser Doppler blood flowmeter during LDL apheresis. Ther Apher Dial. 2007 Oct;11(5):325-30.

28. Li TS, Kubo M, Ueda K, Murakami M, Ohshima $M$, Kobayashi T, et al. Identification of risk factors related to poor angiogenic potency of bone marrow cells from different patients. Circulation. 2009 Sept 15;120(11 Suppl1): S255-61.

29. Reinisch A, Bartmann C, Rohde E, Schallmoser K, Bielic-Radisic V, Lanzer G, et al. Humanized system to propagate cord blood-derived multipotent mesenchymal stromal cells for clinical application. Regen Med. 2007 Jul;2(4):371-82.

30. Wollert KC, Meyer GP, Lotz J, Ringes-Lichtenberg $\mathrm{S}$, Lippolt $\mathrm{P}$, Breidenbach $\mathrm{C}$, et al. Intracoronary autologous bonemarrow cell transfer after myocardial infarction: the BOOST randomized controlled clinical trial. Lancet. $2004 \mathrm{Jul}$ 10-16;364(9429):141-8

31. Li TS, Murakami M, Kobayashi T, Shirasawa B, Mikamo A, Hamano K. Long-term efficacy and safety of the intramyocardial implantation of autologous bone marrow cells for the treatment of ischemic heart disease. J Thorac Cardiovasc Surg. 2007 Nov; 134(5):1347-9.
32. Chandran S. What are the prospect of stem cell therapy for neurology? BMJ. 2008;337:a1934.

33. Li TS, Kubo M, Ueda K, Murakami M, Mikamo A, Hamano K. Impaired angiogenic potency of bone marrow cells from patients with advanced age, anemia, and renal failure. J Thorac Cardiovasc Surg. 2010 JFeb;139(2):459-65.

34. Schanzer A, Conte MS. Critical limb ischemia. Curr Treat Options Cardiovasc Med. 2010 Jun;12(3):214-29.

35. O'Neill TJ 4th, Wamhoff BR, Owens GK, Skalak TC. Mobilization of bone marrow-derived cells enhances the angiogenic response to hypoxia without transdifferentiation into endothelial cells. Circ Res. 2005 Nov 11;97(10):1027-35.

36. Fernandez N, McEnaney R, Marone LK, Rhee RY, Leers S, Makaroun M, et al. Predictors of failure and success of tibial interventions for critical limb ischemia. J Vasc Surg. 2010 Oct;52(4):834-42.

37. Kim SW, Kim H, Cho HJ, Lee JU, Levit R, Yoon YS. Human peripheral blood-derived CD31+ cells have robust angiogenic and vasculogenic properties and are effective for treating ischemic vascular disease. J Am Coll Cardiol. 2010 Aug 10;56(7):593-607.

38. Huang NF, Niiyama $H$, Peter $C$, De A, Natkunam $Y$, Fleissner F, et al. Embryonic stem cellderived endothelial cells engraft into the ischemic hindlimb and restore perfusion. Arterioscler Thromb Vasc Biol. 2010 May;30(5):984-91.

39. Guiducci S, Porta F, Saccardi R, Guidi S, Ibba-Manneschi L, Manetti $\mathrm{M}$, et al. Autologous mesenchymal stem cells foster revascularization of ischemic limbs in systemic sclerosis: A case report. Ann Intern Med. 2010 Nov 16;153(10):650-4.

40. Lian $Q$, Zhang $Y$, Zhang J, Zhang HK, Wu X, Zhang $Y$, et al. Functional mesenchymal stem cells derived from human induced pluripotent stem cells attenuate limb ischemia in mice. Circulation. 2010 Mar 9:121(9):1113-23

41. Kim MH, Zhang HZ, Kim SW. Combined growth factors enhanced angiogenic potential of cord blood-derived mononuclear cells transplanted to ischemic limbs. J Mol Cell Cardiol. 2011 Nov;51(5):702-12.

42. Tse HF, Lau CP. Therapeutic angiogenesis with bone marrow-derived stem cells. J Cardiovasc Pharmacol Ther. 2007 Jun;12(2):89-97.

43. Emerson JF, Emerson SS. Evaluation of a Standardized Procedure for Counting Microscopic Cells in Body Fluids. J Clin Lab Anal. 2005;19(6):267-75.

44. Santillán Benítez JG, Núñez Delira CN, Morales Ávila E, Mejía García E. Validación del método analítico del citómetro XE-2100 y comparación con el método convencional para el conteo de leucocitos en líquidos corporales. Rev Mex Patol Clin. 2009 Oct-Dec;56(4):278-82. Spanish.

45. McGinley M, Wong LL, McBride JH, Rodgerson DO. Comparison of various methods for the enumeration of blood cells in urine. J Clin Lab Anal. 1992;6(6):359-61

46. Phelan MC, Lawler G. Cell counting. Curr Protoc Cytom. 1997 May; Appendix 3: Appendix 3A.

47. Li TS, Furutani A, Takahashi M, Ohshima M, Qin SL, Kobayashi T, et al. Impaired potency of bone marrow mononuclear cells for inducing therapeutic angiogenesis in obese diabetic rats. Am J Physiol Heart Circ Physiol. 2006 Apr;290(4):H1362-9.

48. Barcelos LS, Duplaa C, Kränkel N, Graiani G, Invernici $G$, Katare $R$, et al. Human CD133+ progenitor cells promote the healing of diabetic ischemic ulcers by paracrine stimulation of angiogenesis and activation of Wnt signaling. Circ Res. 2009 May 8;104(9):1095-1102.

49. Cubbon RM, Rajwani A, Wheatcroft SB. The impact of insulin resistance on endothelial function, progenitor cells and repair. Diab Vasc Dis Res. 2007 Jun;4(2):103-11.
50. Zhang D, Li Y, Zhu T, Zhang F, Yang Z, Miao D. Zinc supplementation results in improved therapeutic potential of bone marrow-derived mesenchymal stromal cells in a mouse ischemic limb model. Cytotherapy. 2011 Feb;13(2):156-64.

51. Song HJ, Lan BS, Cheng B, Zhang KF, Yan HW, Wang WZ, et al. Peripheral blood stem cell transplantation for ischemic femoral head necrosis. Transplant Proc. 2010 Jun;42(5):1862-4.

52. Rajantie I, IImonen M, Alminaite A, Ozerdem U Alitalo K, Salven P. Adult bone marrow-derived cells recruited during angiogenesis comprise precursors for periendothelial vascular mural cells. Blood. 2004 Oct 1;104(7):2084-6.

53. Kim MS, Lee CS, Hur J, Cho HJ, Jun SI, Kim TY, et al. Priming with angiopoietin-1 augments the vasculogenic potential of the peripheral blood stem cells mobilized with granulocyte colony-stimulating factor through a novel Tie2/Ets-1 pathway. Circulation. 2009 Dec1:120(22):2240-50.

54. Werner N, Nikening G. Influence of cardiovascular risk factors on endothelial progenitor cells: limitations for therapy? Arterioscler Thromb Vasc Biol. 2006 Feb;26(2):257-66.

55. Mauer K, Exaire JE, Stoner JA, Guthery LD, Montgomery PS, Gardner AW. Reduced high-density lipoprotein level is linked to worse ankle brachial index and peak oxygen uptake in postmenopausal women with peripheral arterial disease. Angiology. 2010 Oct;61(7):698-704.

56. Amann B, Ludemann C, Ratei R, Schmidt-Lucke JA. [Autologous bone-marrow stem-cell transplantation for induction of arteriogenesis for limb salvage in critical limb ischaemia]. Zentralbl Chir. 2009 Aug;134(4):298-304. German.

\section{THE AUTHORS}

Rafael A. Gómez Baute (Corresponding author: gomez@jagua.cfg.sld.cu), hematologist. Assistant professor, hematology service, Dr Gustavo Aldereguía Lima University General Hospital, Cienfuegos, Cuba.

Julio D. Fernández Águila, Hematologist. Assistant professor and assistant researcher, hematology service, $\mathrm{Dr}$ Gustavo Aldereguía Lima University General Hospital, Cienfuegos, Cuba.

Maritza Cabrera Zamora, hematologist. Associate professor, hematology service, Dr Gustavo Aldereguía Lima University General Hospital, Cienfuegos, Cuba.

Ivón Marrero Rodríguez, angiologist. Assistant professor, angiology service, Dr Gustavo Aldereguía Lima University General Hospital, Cienfuegos, Cuba.

Nancy Ramírez Martínez, angiologist. Assistant professor, angiology service, Dr Gustavo Aldereguía Lima University General Hospital, Cienfuegos, Cuba.

Ivet Álvarez García, family physician and angiologist, Dr Gustavo Aldereguía Lima University General Hospital, Cienfuegos, Cuba.

Submitted: September 19, 2011

Approved for publication: July 20, 2012

Disclosures: None 